\title{
Research and Reflection on Construction and Planning of Process Equipment and Control Engineering Specialty*
}

\author{
$\mathrm{Na}$ Xiao \\ School of Mechanical Engineering \\ Huanghe Science and Technology University \\ Zhengzhou, China 450000 \\ Hui Li \\ School of Mechanical Engineering \\ Huanghe Science and Technology University \\ Zhengzhou, China 450000
}

\author{
Huixue Liu \\ School of Mechanical Engineering \\ Huanghe Science and Technology University \\ Zhengzhou, China 450000 \\ Chunxia $\mathrm{He}$ \\ School of Mechanical Engineering \\ Huanghe Science and Technology University \\ Zhengzhou, China 450000
}

\begin{abstract}
The process equipment and control engineering specialty is the applied technology specialty combining electromechanical control with chemical application technology. With the construction and development in recent years, it has become one of the key development majors of the college with obvious characteristics and strong specialty in the construction and training of applied innovative talents in the central plains economic zone.
\end{abstract}

Keywords-process equipment and control engineering specialty; construction and planning; research and reflection

\section{INTRODUCTION}

"Process equipment and control engineering specialty" is characterized by "chemical equipment design". And it requires training students with innovative capabilities, practical hands-on capabilities, and the ability to analyze and solve practical problems in complex projects. These capabilities are reflected in the support of curriculum system and the exercise of practice platform.

\section{GUIDING IDEOLOGY OF PROFESSIONAL CONSTRUCTION}

With taking "undergraduate education+professional skills training" as the starting point, the colleges and university

*Fund project: This article is supported by one of the research achievements of teaching reform project of Huanghe Science and Technology University in 2017 - "Study on the Construction of Application-oriented Undergraduates Specialty Based on the Combination of Production, Teaching and Research - Taking the Example of Process Equipment and Control Engineering Specialty as an Example" (project number: JGYB2017021); one of the research results of "Training Target and Positioning of Process Equipment and Control Engineering" (Project No.: JGZX201714); one of the research results of demonstration course project of teaching reform, innovation and entrepreneurship education "Integrated Design of Chemical Equipment" (Project No.: JCXK201715); one of the research results of the ninth batch of Henan Province Machinery Manufacturing and Its Automation Key Discipline Construction Project. should take transitional development as an opportunity. On innovation and entrepreneurship education, the colleges and universities will cultivate application-oriented innovative and entrepreneurial specialized technical personnel suitable for the construction and development of the Central Plains Economic Zone. And it would create an application-based entrepreneurship personnel training platform with professional advantages of "chemical equipment design".

\section{THE OVERALl GOAL OF SPECIALTY CONSTRUCTION}

The colleges and universities would cultivate applicationoriented innovative and entrepreneurial specialized personnel. The cultivation should be based on the comprehensive development of Central Plains Economic Zone. They should cultivate the students with the development of virtue, intelligence, body and beauty. The students would have solid foundation, strong practice ability, and innovation and entrepreneurship spirit. And these students would work in the design, development, operation and management of chemical equipment.

\section{MAIN CONSTRUCTION CONTENT}

According to the basis of process equipment and control engineering and the current major problems, the professional development, construction planning and personnel training positioning, this paper mainly takes several aspects of the innovation and entrepreneurship development and chemical equipment design and other major contents as the key construction contents.

\section{A. To Improve the Training Program}

In-depth education and teaching seminars are conducted. And the research is conducted from training objectives, training contents, training methods and means, training effects and personnel training results, serving the society, 
and so on. Then, it would form a set of personnel training programs adapted to the transformation and development, and innovation and entrepreneurship. It has implemented teaching process monitoring in the entire process. And it would form a professional personnel training program for their own characteristics and positioning of education [1].

\section{B. The Construction of Teaching team}

Focusing on transformation and development, innovation and entrepreneurship education, and the professional characteristics of chemical equipment design, the colleges and universities will build a teaching and research team that can make teaching and learning with more reasonable structures.

\section{Course Construction}

The curriculum teaching system and content should be optimized, and the course syllabus should be improved. The curriculum content should reflect the cultivation of students' knowledge, qualities and abilities. It would create professional characteristics and advantages. The colleges and universities should strengthen the construction of online courses and exquisite courses, and strive for establishing one or two city-level exquisite courses.

\section{Teaching Material Construction}

Focusing on the training objectives and professional characteristics of talents, the colleges and universities will use special materials that are suitable for professional development. The colleges and universities should actively prepare application-type teaching materials that are suitable for professional development. The teaching material should be concise and simple. The teaching material should focus on key issues. On the basis of sufficient theory, we will focus on creating professional content for application-oriented innovative talents for professional development and personnel training.

\section{E. Laboratory Construction}

The colleges and universities should foster the cultivation of application-oriented innovation and entrepreneurial talents, strengthen the construction of professional laboratories and specialized laboratories, increase comprehensive and design professional laboratories, and establish open laboratories. It would provide necessary and basic conditions for discipline and profession development.

\section{F. Construction of Practice Base}

On the one hand, we will build a stable off-campus practice base, strive to build 2-3 off-campus practice bases, and make full use of the existing "First Tractor Group" training base.

\section{G. Teaching Reform and Teaching Research}

The colleges and universities should strengthen the application of teaching reforms and teaching research projects. We should make this major be a key specialty in Zhengzhou. And we should also strengthen basic teaching and research. In the aspect of teaching reforms, the college should strive to obtain 1 department-level teaching reform research project within 2-3 years and apply for a provinciallevel education reform project. In terms of teaching achievement awards, we will strive to obtain 1- 2 items of department-level teaching achievements within 2-3 years.

\section{H. Teaching Management and Quality Assurance}

The college would use modern management techniques and concepts, and strengthen teaching management. The teaching management is more effective, more standardized, and more humane.

\section{MAJOR MEASURES}

\section{A. Talent Cultivation Mode and Training Program}

The college invites the experienced experts in chemical companies and sibling colleges to conduct teaching seminars. Taking professional characteristics and talent positioning as the starting point, the college would formulate more reasonable course systems, curriculum content and practical links, and pay attention to knowledge ability and quality cultivation, increase the proportion of practice teaching, strengthen practical ability training, and improve students' design and process content training [2].

We will earnestly study and make full use of social resources to run schools. Also, the college should integrate school education, social practice, and employment.

\section{B. Construction and Planning of Teacher Team}

The teaching staff is the core of professional construction. Based on the professional construction and development trend, the structure of the teaching staff should be improved. The training of academic leaders and key teachers should be strengthened. And the annual mission plan is formulated for the academic leaders and key teachers. The college would adopt various and multi-channel approaches to train teachers who meet the requirements and needs of professional education. Young teachers are regularly assigned to study in enterprises. The experienced teachers are arranged to help new teachers who have just entered the service. The college will strive to build professional and integrated professional teaching staff. These teaching staff will diligently study business, love and respect work, have strong teaching ability and rich practical experience. And we must establish this team within 3-5 years.

\section{Curriculum Construction and Planning}

In the aspect of curriculum reform, the curriculum system and course teaching content are optimized, and the cultivation of innovative talents is the goal. Innovative project cases are added to professional courses, and more highly-engineered courses are added to increase the application of "ANSYS Application". It should highlight professional design capabilities.

Within 1-2 years, more than $80 \%$ of professional courses and professional basic courses use multimedia teaching. 
Within 3-5 years, characteristic courses are required to construct online courses and exquisite courses.

\section{Construction and Planning of Teaching Material}

The college should strict teaching material selection system, select teaching materials, professional basic courses, professional course selection and professional personnel training adapted to the professional characteristics and professional personnel.

The college should encourage teachers to prepare teaching materials and give full consideration to the aspects such as the evaluation of job titles and conditions for employment.

\section{E. Practical Teaching Process}

The college should strengthen the construction of "professional laboratories for process equipment and control engineering" and "basic comprehensive experimental devices for process equipment and control engineering". The professional responsible person draws up plans and schedules for professional laboratory construction, and strives to build one in 3-5 years. It would meet the requirements of professional teaching and research platforms.

The college should strengthen the construction of practice base, especially the off-campus practice base. The professional person should take the lead and use 2-3 years to establish stable extra-curricular teaching bases in and around Zhengzhou City or nearby cities with various resources.

The college should strengthen the development of the laboratory, formulate appropriate policies and measures, and encourage the opening of laboratories.

\section{F. Teaching Research}

The college should encourage teachers, especially young teachers, to actively participate in teaching reform and teaching research. After the graduation, the college should organize relevant teachers to conduct teaching seminars to discuss teaching experiences together, and evaluate the progress of teaching research topics. On the one hand, we will conduct research on the application and promotion of teaching research results, strive to use 3-5 years to write 5-8 items of teaching reform projects, and publish 10-15 professional research papers on teaching reform.

\section{G. Teaching Management}

The teaching management will be held at the end of each semester. It should effectively implement various management regulations. According to the quality standards of each major teaching link, teaching evaluation and inspection system with professional characteristics will be established.

The college should use modern management techniques such as networking. It would build an interactive platform for teachers and students.

The teachers cooperate with relevant departments of schools and colleges to conduct surveys and statistics on enrollment and employment. And the college should carry out quality follow-up surveys on graduate students.

The college should strive to establish teaching evaluation, inspection programs and indicators based on different phases or time points in all professional teaching courses before 2020. The major professional courses are all web-based courses.

\section{H. To Create Professional Features and Advantages}

The company specializes in the design of chemical equipment, strengthens its links with disciplines such as chemical machinery and information engineering, and maintains professionalism that focuses on engineering and emphasizes the intersection of disciplines.

\section{CONCLUSION}

In the process of professional construction, the college should take the talent training goal as the benchmark. We should work hard to cultivate local application-oriented personnel training models, further optimize the professional structure, and comprehensively upgrade the overall level of the process equipment and control engineering specialty. And teaching conditions, teaching staff, talents, training mode, personnel training program, curriculum system, teaching methods, teaching content and teaching reforms have competitive advantages and characteristics.

\section{REFERENCES}

[1] Tang Weidong, Li Jinzhong, Guo Chen et al. Exploration and Practice of Cultivating Innovative Talents in Characteristic Specialty Construction [J]. Journal of Jinggangshan University. 2009, 10(30): 30-32. 唐卫东, 李金忠, 郭晨等. 特色专业建设中创新人才培养的 探索和实践 [J], 井冈山学院学报. 2009, 10(30): 30-32.

[2] Guo Yecai, Han Yingge, Zhou Qiaoxi et al. Exploration and Practice of Training Innovative Talents in Higher Education [J], Journal of Anhui University of Science and Technology. 2003, 1(8): 78-80. 郭 业才, 韩迎鸽, 周巧喜等. 高等教育中创新人才培养的探索与实践 [J], 安徽理工大学学报. 2003, 1(8): 78-80. 